\title{
Knowledge and practice in mental health nursing care
}

\author{
Saberes e fazeres no cuidado de enfermagem em saúde mental \\ Saberes y que haceres en el cuidado de enfermería en salud mental
}

\begin{abstract}
Teresa Cristina da Silva Kurimoto', Claudia Maria de Mattos Penna", Débora Isane Ratner Kirschbaum Nitkin"'I
' Universidade Federal de Minas Gerais, School of Nursing, Department of Applied Nursing. Belo Horizonte, Minas Gerais, Brazil.

"Universidade Federal de Minas Gerais, School of Nursing, Department of Mother-Child and Public Health. Belo Horizonte, Minas Gerais, Brazil.

I' University of Toronto, Lawrence S. Bloomberg Faculty of Nursing. Toronto, Canada.
\end{abstract}

\section{How to cite this article:}

Kurimoto TCS, Penna CMM, Nitkin DIRK. Knowledge and practice in mental health nursing care. Rev Bras Enferm [Internet]. 2017;70(5):973-80. [Thematic Edition "Good practices and fundamentals of Nursing work in the construction of a democratic society"] DOI: http://dx.doi.org/10.1590/0034-7167-2016-0343

Submission: 07-13-2016 Approval: 02-08-2017

\section{ABSTRACT}

Objective: To understand mental health nursing care based on the concept of the subject of the unconscious proposed by Lacan. Method: A narrative study was carried out with 19 nurses, chosen based on their theoretical approach or referral by other participants, through the snowball sampling technique. The interviews were carried out in person or digitally, and were recorded and fully transcribed. Results: The analysis was carried out based on Freudian and Lacanian psychoanalysis, approaching nursing care as it acts on the body, secretions, and excretions, to distinguish it from the spirit of fineness. Effects on care are discussed, considering the subject of the unconscious with its knowledge, creating unique exits (sinthome). In this situation, professionals are required to abstain from a position of knowing what is better for the Other. Final considerations: This nursing care perspective offers contributions when discussing the centrality of the subject and words in the care process.

Descriptors: Nursing Care; Psychoses; Psychoanalytic theory; Narration; Mental Health.

\section{RESUMO}

Objetivo: Compreender o cuidado de enfermagem em saúde mental a partir da concepção de sujeito do inconsciente proposta por Lacan. Método: Pesquisa narrativa, realizada com 19 enfermeiros, determinados por meio de abordagem teórica ou indicação de outro participante, pela técnica de snowball. As entrevistas foram realizadas pessoalmente ou por meio digital, gravadas e transcritas na íntegra. Resultados: Da análise, fundamentada na psicanálise freudiana e lacaniana, tomou-se o cuidado de enfermagem em seus atos sobre o corpo, suas secreções e excreções, para localizá-lo a partir do espírito de fineza. Discutem-se os efeitos para o cuidado quando se considera o sujeito do inconsciente com seu saber construindo saídas únicas - Sinthoma. Essa condição requer do profissional abster-se de uma posição de saber o que é melhor para o outro. Considerações finais: Essa perspectiva de cuidado de enfermagem traz contribuições ao problematizar a centralidade do sujeito e da palavra nas práticas de cuidado.

Descritores: Cuidados de Enfermagem; Psicoses; Teoria Psicanalítica; Narrativa; Saúde Mental.

\section{RESUMEN}

Objetivo: Comprender el cuidado de enfermería en salud mental a partir de la concepción del sujeto del inconsciente propuesta por Lacan. Método: Investigación narrativa, realizada con 19 enfermeros, determinados mediante abordaje teórico o recomendación de otro participante, por técnica de snowball. Entrevistas realizadas personalmente o por medio digital, grabadas y transcriptas integralmente. Resultados: Del análisis, fundamentado en el psicoanálisis freudiano y lacaniano, se tomó la atención de enfermería en sus actos sobre el cuerpo, sus secreciones y excreciones, para localizarlo a partir del espíritu de delicadeza. Se discuten los efectos para la atención cuando se considera el sujeto del inconsciente con su saber construyendo salidas únicas - Sinthoma. Esa condición requiere que el profesional se abstenga de una posición de saber qué es mejor para el otro. Consideraciones finales: Esta perspectiva de atención de enfermería determina contribuciones al problematizar la centralidad del sujeto y la palabra en las prácticas de cuidado.

Descriptores: Atención de Enfermería; Trastornos Psicóticos; Teoría Psicoanalítica; Narración; Salud Mental. 


\section{INTRODUCTION}

Nursing care in the mental health area has been going through changes in the last few decades. The psychiatric reform movement has been consolidated since the 1980s; it has as its foundation the citizenship of persons diagnosed with psychiatric disorders in a society without psychiatric hospitals ${ }^{(1)}$. Substitute services (centers of psychosocial care-CAPS, as per its acronym in Portuguese) represent the possibility of "a way of care that considers the suffering of subjects as a structuring element of expanded clinics that articulates them in their territory and does not confine them in order to treat them" ${ }^{\prime \prime 1}$. This context requires continuing efforts to find new ways to host and provide care.

In this community care context, which values citizenship, providing care means focusing on unique aspects of the daily lives of subjects. Therefore, care that was previously exclusively assigned to nursing, is given centrality in therapeutic projects focused on psychosocial care $^{(2)}$.

In psychosis, subjects face daily difficulties; in crises, they may become estranged from themselves, leading them to believe that their ideas came from outside ${ }^{(3-4)}$. This reality leads to specific subjective difficulties that have an impact on the way these subjects perceive themselves and build social relationships. Psychosis can also lead to the development of peculiar ways of dealing with one's own body. The chaos of punctures may provide experiences of a shattered and pitted body ${ }^{(4)}$. It may also become a last resource to deal with subjective experiences of estrangement from themselves, in which subjects believe they are invaded or controlled, sometimes creating the conditions for self-mutilation. All of these phenomena are produced from unconscious knowing ${ }^{(5)}$.

This way of conceptualizing psychosis is supported by the concept of the subject, which is understood to mean that there is no subject, in essence, a person. It is not about the imaginary I (that by which I define myself saying "I am..."). It is about the evanescent subject, captured in speech. Precisely from lapses that prove the existence of an unconscious structured as language, in the form of metaphors and metonymies, the subject is what arises from inter-signifiers to disappear immediately ${ }^{(6)}$. Therefore, taking the subject in their close connection with the language, it is stated that "the speech act emerges less as communication than as the foundation of the subject, in an essential enunciation"(7).

In his second seminar, Lacan encounters the work of the writer James Joyce, with its joined words, which, although meaningless, stand out in the text. Lacan offers the interpretation that Joyce, in the face of the impossibility of responding to the requirements of the Other, creates a unique exit. Unsupported by the language, Joyce becomes master and creates a non-analyzable way of speaking, scheming to fashion for himself a unique way of binding the records of the imaginary, symbolic, and real: Joyce thus becomes master of la langue (Fr. "language."). Lacan called this "Sinthome," and it is the logic that guides Lacan's second seminar ${ }^{(8)}$.

Lacan makes use of this logic to state that each subject, psychotic or not, in the face of the requirements of the Other, herein understood as life, constructs unique enunciations among the real, imaginary, and symbolic. Thus, each subject produces unique responses to the obstacles inherent to life. In this sense, psychosis is no longer thought by the logic of deficit and becomes the model of what happens with each subject. Some will shape this in analysis. Others, like Joyce, will create this construction by themselves ${ }^{(8)}$, by simply finding someone who is able to function as a receptacle for their experience and speech, as already evidenced in other studies ${ }^{(2)}$.

Based on the concepts of subject and psychosis, the following questions emerge: What knowledge on nursing care could or can be constructed? What principles and care devices could or can be constructed? This discussion may offer new contributions to the knowledge and practice of nursing in mental health, which is relevant in the current context of the Brazilian mental health sector. Therefore, the objective of the present study was to understand mental health nursing care, based on the concept of the subject of the unconscious proposed by Lacan.

\section{METHOD}

\section{Ethical aspects}

The present study complied with all ethical principles on research involving human subjects and was approved by the Research Ethics Committee of the Faculty of Medical Sciences at the University of Campinas (UNICAMP).

\section{Theoretical-methodological framework and type of study}

This was a narrative study based on the ideas that "...language mediates [sic] action; the narrative is the central structure of the way human beings build meaning, that is, the life course and personal identity are experienced as a narration." ${ }^{\prime(9)}$ Therefore, in a narrative, an interpretation of something that occurred is carried out by the narrator, and will subsequently be reinterpreted by the researcher ${ }^{(9)}$. The theoretical foundation utilized was the psychoanalytic theories of Freud and Lacan, especially the concepts of the unconscious, the subject, speech, and sinthome (this last was extracted from the Lacan's second seminar). This article originates from the doctoral thesis entitled "Mental health nursing care from the perspective of the subject's clinic: questions of fineness".

\section{Study setting and data source}

The study's setting was the entire Brazilian territory. Nineteen nurses participated. They met the following inclusion criteria: to be working in the mental healthcare area and to recognize that this care is provided based on Lacanian theoretical influences. The sample was obtained by means of theory-based and snowball sampling techniques ${ }^{(10-11)}$. Six key informants were found through their scientific publications on the theme of nursing care and psychoanalytical theory; they, in turn, referred other nurses. Thirty nurses were found, of whom eight felt they did not meet the criterion based on theory ${ }^{(11)}$, and three did not respond to contact. The participants were identified by the letter "N," followed by Arabic numerals according to the order of the interviews. 


\section{Data collection and organization}

The narratives were obtained by means of interviews. The participants were asked to describe their work with psychotic patients, using scenes from their daily work. The interviews were carried out in private locations chosen by the participants. They were recorded in audio and video with the participants' permission, and later transcribed. The interviews were synchronous in time or asynchronous in space ${ }^{(12)}$. The transcripts were made available to the participants for additions or corrections.

\section{Data analysis}

The narratives extracted from the interviews were fully analyzed, that is, all content of the narratives was interpreted, keeping the reference to the whole of the interviews, as well as to the context of the narrative told ${ }^{(13)}$, in accordance with the Freudian and Lacanian psychoanalytical theories. Language aspects in the narratives were analyzed, that is, the metaphors and denominations used by the narrators. After each narrative, the reading carried out by the researchers was presented. Analyzing a narrative also means sharing what happened during the interview. This was achieved by the reading or understanding that researchers had about what was told, what they absorbed from the narrative, and how they rewrote $\mathrm{it}^{\left({ }^{(13)}\right.}$.

\section{RESULTS}

Nursing care in psychosis: Shield of beauty or care and their things of fineness

Narrative 01 emerged from the question regarding concepts about and knowledge of mental health nursing care.

Because I arrived there and nobody used toilet paper! I implemented the use of toilet paper... Therefore, in this institutional life, which I find very difficult, I always resume my occupation. My occupation as a nurse, in this place. I arrived at the psychiatric hospital, and the patients, they did not go to the activities anymore..

No, they are old, they do not want anymore.

They did not use toilet paper.

They do not learn to use toilet paper. They will throw it away.

I, for believing that while... Well, in the matter of the environment. It must be an incarnation of Freud... of Florence, to think that "No, they can handle this!"-But I also want to know about what I can handle. There was a woman, L., to whom I refer. She only cleaned her anus on the corner (angle) of the bathroom door. It even wore out! Folks, after three years, L. is using toilet paper, now that she has it, almost $95 \%$ of the time. Because now she has it.

This week, the toilet had to be removed! (She gives a great laugh) Because the type of toilet paper changed, and now it is that large one. Then, C. put everything inside the toilet, and it had to be removed. Then, a professional came to talk to me.
They had to remove the toilet.

Yes, but you are not thinking that we will stop using toilet paper just because she blocked the toilet. The toilet will be removed again. It will be unblocked. However, we were able to make people start using toilet paper. I made people start thinking about this. ... (N15)

\section{DISCUSSION}

It may seem strange, even contradictory, to initiate a discussion with a title that promises talk of beauty and fineness with a narrative in which something so raw and primary is at issue. Small children are taught to clean themselves after elimination. To clean patients, or keep them clean after elimination is related to a basic need and is taught as foundational nursing to students who graduate from nursing programs

Nursing involves this reality: Its practice is marked by the concreteness of the body in its reality, the organism with its secretions and excretions, with its real and inexorable corporeal condition. This body/organism, this real body, is intrinsically linked to the symbolic and imaginary, that is, the two other ways of representing the body. However, the experience of the body as shattered, non-integrated, and organized by its functions produces unusual ways of dealing with itself $\mathrm{f}^{(14)}$. In the narrative presented, this way of cleaning the anus may confirm this shattering, which generates an unusual relationship with the body.

Therefore, nursing care is not just about the concreteness of the organism. When providing care and volunteering as a reference for this woman, the result is not a patient who is more conscious of the best way to perform her personal hygiene. Somehow, this care creates conditions so that the simple act of using toilet paper can happen. However, it is important to know that this care must not (and here it is really about duty) fail to maintain some minimums, so that nursing care can be talked about. These minimums, as indispensable elements, can be called minimum standards. This because, if they are not present, it is not even possible to say that care is provided.

However, care is necessary, based on these minimum standards, and professionals do not have to be able to meet all needs. That is, professionals must be attentive to what they are able to handle, thus determining and assuming what they are not able to do. Therefore, professionals must also assume their situation as subjects, considering the existence of a structural absence around which the subject is constructed ${ }^{(6)}$.

Moreover, nursing care does not always mean being around things of high social prestige. The narratives reveal: a patient who cleaned herself on the door jamb; patients who took collective baths (N15); a patient with skin lesions who was always touching them in "the name of God" (N13); a patient who cut herself with a piece of glass (N16); a patient who "takes us [student and teacher] to the bathroom, urinates, defecates, and shows it to us!" (N18). Patients who, because of their suffering, find in the body/object, in this body pitted by punctures, unusual exits ${ }^{(7)}$.

Miller ${ }^{(15)}$ stated that a good education is expected to indicate what can and cannot be done with each part of the body. Therefore, from an early age in our families, we learn about 
typical solutions to deal with the problem of appropriate uses of the body: "With this, you must do this, with that, you must not do this. This division does not work with schizophrenics"(15). As a result, psychotics find themselves captured, without the aid of any of the established speech, by this body of organs subverted in their functions ${ }^{(7)}$. This is because psychotics place themselves out-of-speech ${ }^{(6,16)}$, and not out-of-language.

Speech is understood as an unconscious symbolic relationship, assuming that those who are involved are submitted to castration $^{(7)}$. Subjects submitted to castration know, even unconsciously, that they cannot do everything, cannot say everything about everything, will never be able to fully meet their desires, but will nonetheless remain restricted to the voracious and deadly desire of the Other, once they realize that this Other is also barred in its desire, that is, the Name-of-the-Father is also inscribed there. Because of this lack of fulfilment, the subject seeks to build ways of dealing with it, to deal with their desires. Psychotics, being out-of- speech and unable to move around the speeches, are responsible for building possible social relationships, with possibilities of some kind of recognition ${ }^{(16)}$.

However, at the same time, psychotics become masters of speech: their confusing speech allows anything to be said, and at the same time, undoes what was established, instituted, and known, rejects connections between signifiers and meaning, undoes articulations, and subverts the incidence of signifiers in the body ${ }^{(16)}$. Precisely in order to reverse everything. Precisely in order not to stabilize in any of their speech, thus sometimes making small incursions ${ }^{(8,16)}$.

In this narrative, when the narrator sees the lack of basic hygiene conditions and sees the patient cleaning herself repeatedly on the door jamb, she resumes her occupation as a nurse, based on the concepts of the master founder Florence Nightingale, and carries out her reading: L. cleans herself in an unusual even grotesque, way, exposing herself to risks, making the environment uglier and stinkier. This is something that makes the possibility of social relationships difficult. Based on this, there is a minimum: the implementation of toilet paper.

However, this same reality allows some inferences. Anuses and toilet paper may be approached as elements that take on unusual uses. Toilet paper, in contrast to its usual purpose, is used for the ludic, perhaps pleasant, act of unfolding. Moreover, as unfolded paper, now without a use, it gains a new use: the purpose, in its excess, of clogging.

Similarly, the body has several "usages." While inhabited by speech, the body of a speaker, the symbolic body, is subject to being divided by its organs, to the point of having to find them a function ${ }^{(7)}$. The body, in psychosis, the enigmatic body ${ }^{(14)}$, is found pitted by punctures, disorganized ${ }^{(7)}$, a body that is offered for pleasure. This makes possible the reading that, in addition to providing cleanliness, for L., there are different ways of using this body, in which the circulation of the signifiers, as well as the signifier chain, is found to be fragmented $^{(17)}$. In this condition of fragmentation, something does not drain; it stems and is dammed up. In the face of this reality, it slips from Florence Nightingale to Freud: To make the environment more pleasant to look at, be in, and recognize, in this concreteness, disorganization, and lack of "good education," there is a subject who is creating things to do with their body and suffering, creating a new body ${ }^{(14-15)}$. In addition, the professional, when questioning the knowledge already known (They do not learn to use toilet paper. They will throw it away. N15), creates ways of taking this crystallized knowledge to its limits and enabling the words to circulate. However, maybe for this to happen, the toilets need to be removed.

Therefore, it must be considered that care, although it can first focus on the body, its organs, and its functions, also ends up dealing with the fact that organs are significant, that is, the function of the organs comes from speech $^{(7)}$. Something like this emerges from Narrative 02, in which this knowledge of the body is considered, as well as its possibility of transmission:

So, the student... It was really funny, because we worked together, and transmission is something very artisanal. The patient, every time she went to the bathroom, took the student with her. This brought questions for the student. The student said: "Teacher, nursing care is making her wash her hands after urinating and defecating." Well, washing hands after her necessities is something really important. But before, read this: Why does someone have to take others to see her urinating and defecating? What can we do to change this situation? So, let's try to separate it. Let's try to separate this production from her body, let's see what this is, to see if we can get a separation and a word between. To have a new word instead of defecate, or replace defecate with another word. Then comes reading with the student. (N18)

The narratives of N15 and N18 can be analyzed in their association with language. Nevertheless, the fact that both are marked by the act and its repetition (cleaning the anus on the door jamb [N15]; seeing her urinate and defecate [N18]) cannot be ignored. By means of an act, something insists that it can be understood as mere repetition, that is, "the same again." However, in this act, there is another possibility of reading, which N18 seems to have adopted: understanding of the act as having a quality of speech without words ${ }^{(18)}$. For Lacan, this speech without words, although it does not hold enunciations, is of the order of language, placed in the field of enjoyment. This field that deals with the act and is "beyond the principle of pleasure, where the pulse of death rules"(16). This field of enjoyment points to repetition, in which perhaps the word, in its function as letters, can inscribe some trace, some mark.

This is equivalent to saying that, often, in mental health/psychiatry nursing care, especially in care of psychotics, there is a body, and its meanings and usages are not always usual. This is where their complexity and difficulty reside, meaning that in this field, there is the mark of a remnant impossible to be named, which, by means of repetition, resists any attempt at significance and brings suffering. Nevertheless, since care is seen and assumed in this manner, possibilities of providing care may be extracted from this complex and difficult condition. However, what possibilities can we talk about, based on a daily life marked by the complex and unusual? What can support this practice?

Narrator 15 talks about an occupation. Savoir-faire may be read in the narrative, not in the nature of a recipe or an example to be followed, but perhaps to show, just as Lacan states ${ }^{(8)}$, 
"that one is responsible only in the measure of its savoirfaire." This knowledge "is the art, the artifice, what gives art for which a significant value is possible, because there is no Other of the Other to carry out the final judgment"(8). No Other of the Other, that is, there is no final truth. With this, all knowledge finds its value. The narrator calls it knowledge of her occupation, to which she always returns, to think about what she is doing in the institution, but also to know about her desire, to rethink "what she can handle." In the final analysis, this means recognizing her condition as a subject, to whom the condition of completeness is barred. However, in addition to occupational knowledge, Narrator 15, in Narrative 03, reaffirms having and using authority.

That is the thing... lunch... why can't you make this in a prettier way? Why does coffee have to be served? Why can't it be served in a coffee cup?

\section{Oh, but they will break it!}

Will they break it? Let's see. Because first, it needs to be served, and then we will see if they will break it or not. They don't! Then, I used my authority. I made it worth something. In mental health, authority is required and must be exclusive. Exclusive, thus it has to rule. (N15)

To what extent should barred subjects place themselves under authority? Although N15 does not talk much about it, Lacan's guidance ${ }^{(6)}$ to analysts may be borrowed:

Psychoanalysts certainly direct the treatment. The first principle of this treatment, which is spelled out at first, is that they must not, by any means, direct the patient. The direction of conscience is herein found to be totally excluded.

A subject, when dialectizing their position and knowledge, is able to institute direction, pointed out, not by desire, but by the logic that supports work. Inspired by a proposal called practice among several ${ }^{(19)}$, this is understood as a clinical strategy that points out direction, a way of organizing the work that considers the subject and operates so that this condition is always recognized. This strategy is organized into four axes: all members of the team place themselves in the condition of partners of the subject; the work is constructed in meetings of the members of the team; one of the professionals is instituted as therapeutically responsible for a specific subject; and, finally, a theoretical direction must be adopted, and at least one of the professionals must be guided by the Lacanian approach to theoretical and clinical reference ${ }^{(19)}$.

In this context, the authority that Narrator 15 refers to may be read: the authority to direct the treatment, establish it, and propose its foundations without slipping toward the patient's direction. And, with this, it can be produced: a displacement in speech: one-quarter rotation (N15); displacement that can, for example, be obtained when crystallized knowledge of patients, which does not allow professionals to see new possibilities, is replaced with the enchantment of these same professionals when they are convinced that it is possible to do something new and different. Consequently, the authority of the narrator becomes the driving element in allowing the emergence of new speech.

In addition, there is another issue regarding this occupational knowledge. When talking about an occupation, Narrator 15 refers to the art of searching for the beautiful by means of artisanal creation: delicate, careful, tireless creation. Narrator 15 understands her job as a nurse, seeking to achieve what art and beauty may exist in the subtleties of this creation. This art may be translated or precisely found in these subtleties, details, and small gestures that, in this institutional creation focused on the collective, seek to ensure the place of the unique. This can be seen in Narrative 04 .

Unfortunately, we still wear uniforms. They are cute pink dresses, and there is a sewing atelier that makes embellishments. So, they make embellishments, belts, fabrics; they make a lot of things that... they make necklaces made of fabric. Then at least, each one has a more individual look. Somebody wears three necklaces, another wears a colorful belt. Sometimes, they lift too much (the skirts)... they put a belt on and they lift too much... I keep talking about the importance of looking different, right? This patient wears three necklaces. She likes them. In addition, she says that her name is not Maria, but Mariah. (N10)

In the simple beauty of embellishments, particular marks are built, distancing subjects a little from being "like everybody." The "one" is built, but mainly, gaps are created that show that the subject with their suffering is able to fit in the institution. Small embellishments, subtleties, little marks that distance them from the condition of belonging to the common run of mentally ill people wearing uniforms. Mariah wears three necklaces, changes her name with the purpose of, perhaps, achieving some sophistication, since she chooses a name whose pronunciation refers to the French language. Or perhaps, simply with the purpose of coating the surface of a suffered life with some subtle beauty, where passages to the act often gain space. Or perhaps nothing of the kind. What is certain is that small beauties, little choices, mark the presence of stubborn singularity that insists. However, this singularity achieves greater consistency when someone, by listening, recognizes $i t^{(6)}$. This singularity works as a barrier to the speech of authority of law and authority of regulation, and may find its counterpoint in authority of star, which, by means of questions, is seen as beyond where it is put ${ }^{(20)}$.

In the face of the real, without signifiers, this something that refers to the death pulse, this emptiness, may favor bureaucratic care that is distanced from individuals and focuses on toilets, institutional regulations, and tactical agreements on behalf of collective inertia, or even carries out every care act in the name of standardized speech (strict rules that everyone has to follow). It is possible to create ways of making a hole in this real, through words or producing shields for it. Beauty, as a shield for the real $^{(18)}$, may be present in the little daily subtleties of life. Narrative 05 points to the search for some aesthetic effect.

We are always with this thing. I wore it a lot up to now... I think that this, the beautiful... it must have beauty... it must, 
right, otherwise it gets complicated. Now, in this place (refers to a mental health institution), there is coffee every day, at ten o'clock in the morning. We filter it. We are now filtering coffee... What for? For its smell... There is a patient who now asks for it. "The smell of coffee. Is it coffee time?" Do you understand? What is it going to improve? You know, the person enjoys a better day. (N15)

The beauty of narratives 04 and 05 is translated into nuances of subtleties that narrators 10 and 15 give to care, when suggesting that the smell of coffee or little embellishments may be aligned with something that also produces subtle therapeutic effects, seeking to achieve singularity. The therapeutic may be found in each one having a more individual look and of the person enjoying a better day.

However, from the theoretical point of view, what guides these clinical strategies? This question has a single answer: the subject and their way of suffering. If the smell of coffee makes the day better, this is then a valid strategy. If, despite the standardization imposed by the uniforms, flowers are made, small printed marks that attest to singularity, this is therapeutic. These are ways of emptying or making holes in the universal and general speech of the institution.

The smell of coffee is seen by the narrator as an element that, when making the environment pleasant, works as beauty, as art. Florence Nightingale ${ }^{(21)}$, an environmentalist theoretician, sees an environment with pure air, that is well-lighted and properly clean, as a way of allowing patients to expend a minimum of energy, so that their bodies can focus on cure. Although what the narrator brings in regarding the smell of coffee does not precisely align with Nightingale's perspective, something about the pleasant smell in the environment creates a sense of welcome.

The environment, taken as the quality of a setting, received some elaboration on the part of Freud ${ }^{(22)}$, but was explored more thoroughly by Winnicott, who was a post-Freudian psychoanalyst. In cases of personal structure not yet integrated, as occurs in psychotic conditions, Winnicott proposed greater emphasis on clinical management and establishment of a setting in which the notion of "holding" becomes central. For Winnicott, holding is understood as to hold, to give support: "Support of certain experiences for a long time without interrupting the experience of the patient. It means offering an environment/setting that supports and enables the integration process of the subject"(23).

However, the approach proposed by Winnicott had as its objective to enable the passage of the experience in the field of fusion I/not-I to the field where a differentiation I/not-I is established. This environment would allow the expression of the desire (such as embellishments, belts, necklaces, and names) and absence. Therefore, included as an important element of treatment, holding may imply acts that are different from traditional analytical practice, since what is at issue here is not the relevance or rigor of clinical practices, but rather, the suffering of the subject ${ }^{(24)}$.

Aligned with the idea of holding, the smell of coffee seems to be something that provides some kind of welcome and support, to the degree that "the day gets better." However, this smell of coffee, a creator of an aesthetic effect, may accomplish, along with holding, which is located on the edge of analytical techniques ${ }^{(24)}$, the role of making an edge. This instils in the institutional environment, which is marked by regulations and rules, some lightness, some subtlety in the form of care, in the form of not completing the institutional speech. Just like holding, this care is inscribed on the edge of traditional care, and maybe for this reason, it works as an edge, as a shield against emptiness, against what cannot be meant, against the real, since the real finds its limit when it is integrated with the imaginary and the symbolic ${ }^{(8)}$. For Lacan ${ }^{(18)}$, this is surely the role of the beautiful, of art.

In analytical speech, the logic of the singular and the idea of creating conditions so that word finds place are considered. If the environment is collective, it is not possible to know what the word will bind or mean to each one. Perhaps not even the subject knows. The embellishments present in narratives 04 and 05 , announce care with a focus on the subject by means of things of fineness.

Pascal, a mathematician and philosopher of the seventeenth century ${ }^{(25)}$, contends that there is a mathematical mind and an intuitive mind, one opposing to the other. Those endowed with a mathematical mind only see what is clear, rough, and concrete. However, there are other elements that can be achieved in the world. For this: "We just have to turn our heads without any effort; it is only about having good sight, but it has to be good, because the principles are so subtle and in such large numbers that is almost impossible not to miss some"(25).

At the same time, it is clear that these principles "...are only glimpsed [...] are things so delicate, that a very delicate and accurate sense is required to feel them [...] most often without being able to demonstrate them in sequence, such as in geometry..."(25). We must be endowed with an intuitive mind to see them.

This intuitive mind causes difficulties, especially for those who have a mathematical mind, a direct $\operatorname{mind}^{(25)}$, and also for those who believe or were led to believe that science resides in the concreteness of things that can only be understood by complex reasoning ${ }^{(26)}$. Therefore, these difficulties sometimes emerge in teaching, just as presented in Narrative 06.

To make students think like that is difficult, because logic is just the reverse. Then, when you put students to make a workshop of Beauty, some of them understand the objective, see it as care, and others say:

But teacher, I will be combing hair? Do I have to wash the patient's head? How is it possible? What is this? I did not come here to wash the patients' head! (N4)

Therefore, care that is based on knowledge of subtleties, occupation, embellishments, smells, and things of fineness, may not be well understood by reason, but, exactly because it comes from the imaginary and symbolic, it may limit the real, which in psychosis, acquires the status of reality, concreteness, certainty.

Psychoanalytical concepts of the unconscious, the subject, speech, and sinthome can be taken by nurses as guiding principles for practice. 


\section{Limitations of the study and contributions to nursing}

Nursing care in general, and psychiatric/mental health nursing care specifically, resists, in the infinite of their practice and singularity of the subjects, to a total significance that says it all. This shows that care goes beyond language, and also shows what happens in the setting of care: unique care, in a single situation. Therefore, analyzing narratives to understand nursing care in its significance is a task that has limits. However, discussing this care from the point of view of scenes in their singularities, in a systemic way, becomes an essential way of rethinking care practices that focus on the subject.

Another limitation of this study is that psychoanalytical theory is not unique. It is influenced by several post-Freudian authors, who have created, in their own psychoanalytic practice, different theoretical schools. The Lacanian theory was used in the present study. Further studies must be carried out with nurses whose theoretical approaches are influenced by other schools of psychoanalysis. It is believed that this may bring new aspects of nursing care to the subject in psychosis, making comparisons possible.

\section{FINAL CONSIDERATIONS}

The analyses undertaken in this article regarding psychiat$\mathrm{ric} / \mathrm{mental}$ health nursing care refer to care that takes place in a context of simple, daily life, seen by some as banal. Precisely because it deals with the body and its odors, excretions, secretions, this care reveals a real against which beauty may work as a possible shield. Therefore, the nurses talk about subtle acts that can produce care effects.

These subtleties may be considered as something that calls what was herein designated as fineness. Not the fineness of the "education that comes from a birthplace", but the fineness of the refinement required in care for psychotics in their condition of "not being like everybody." A fineness that demarcates and supports the position of professionals as apprentices of those who construct the exits for their suffering. It is necessary to understand the psychotic subject, who is the subject of the unconscious, with the knowledge that enables them to construct unique exits for their sinthome. In this context, providing care means professionals must abstain, when thinking of care, from standardizations or universal languages that focus on psychotic patients.

As inspiration, Lacan's suggestions for psychoanalysts were considered, which does not mean that nurses take on the role of analyst themselves. An essential way to make this inspiration possible is the clinical strategy of practice among several, since its pivot and support is in dialogue among members of the team, as long as they are all open to becoming partners of the subject who is suffering. The strategy of practice among several places professionals in the field of the subject. Therefore, nurses are able to create new concepts and perspectives, finding displacement, some dialectic between care made in the body and care that is guided by words.

Carried out based on these principles, mental health/psychiatry nursing care and its things of fineness may be understood as care emptied of previous knowledge. It is care that recognizes that lack of knowledge, and is not carried out by means of general and generalizable standardization. but focuses on the singularity of the subject. It bases its values on this lack of previous knowledge of professionals, and bets on the knowledge of the subject who suffers. The care is guided by the patient's time and not by the institution. It is care that finds in the idea of art, understood as artisanal and created one by one, conditions for dealing with the details and subtleties of daily life, raising them to the level of care.

\section{REFERENCES}

1. Pitta AMF. Um balanço da Reforma Psiquiátrica Brasileira: instituições, atores e políticas. Rev Ciênc Saúde Colet[Internet]. 2011 [cited 2016 Mar 26];16(12):4579-89. Available from: http://www.scielo.br/pdf/csc/v16n12/02.pdf

2. Marques NA, Toledo VP, Garcia APRF. Meaning of psychosis by the subject and its effects on clinical nursing. Rev Bras Enferm[Internet]. 2012 [cited 2016 Mar 26];65(1):116-20. Available from: http://www.scielo.br/pdf/reben/v65n1/17.pdf

3. Freud S. Rascunho H. In: Freud S. Publicações Pré-psicanalíticas e esboços inéditos. Rio de Janeiro: Imago; 1990(1895). Edição Standard Brasileira das Obras completas de Sigmund Freud, 1, 1886-1889. p.290-8.

4. Lacan J. O Seminário: as psicoses. 2 ed. Rio de Janeiro: Jorge Zahar Editor; 1988.

5. Kurimoto TCS, Nitkin DIRK. Vincent van Gogh: um corpo entre o véu da beleza e o horror do real. Rev Psicol Plural[Internet]. 2010 [cited 2016 Mar 26];19(31):41-54. Available from: http://www.fumec.br/revistas/plural

6. Lacan J. Escritos. Rio de Janeiro: Jorge Zahar Editores; 1998(1960). 937p.

7. Lacan J. Outros escritos. Rio de Janeiro: Jorge Zahar Editores. 2003(1953). 607p.

8. Lacan J. O Seminário: O Sinthoma (Livro 23). Rio de Janeiro: Jorge Zahar Editores; 2007(1975-1976). 249 p.

9. Rabelo AO. A importância da investigação narrativa na educação. Rev Educ Soc[Internet]. 2011 [cited 2016 Mar 26];32(114):17188. Available from: http://www.scielo.br/pdf/es/v32n114/a11v32n114.pdf

10. Suri H. Purposeful Sampling in Qualitative Research Synthesis. Qual Res J[Internet]. 2011 [cited 2015 Nov 30];11(2):63-75. Available from: http://www.emeraldinsight.com/doi/abs/10.3316/QRJ1102063

11. Spector-Mersel G. Mechanisms of selection in claiming narrative identities: a model for interpreting narratives. Qual Inq[Internet]. 
2011 [cited 2015 Nov 30];17(2):172-85. Available from: http://qix.sagepub.com/content/17/2/172

12. Janghorban R, Roudsari RL, Taghipour A. Skype interviewing: the new generation of online synchronous interview in qualitative research. Int J Qual Stud Health Well-being [Internet]. 2014 [cited 2015 Nov 30];9(0):1-3. Available from: http://www.ijqhw.net/ index.php/qhw.

13. Lieblich A. About Amos: reading with our heart. Narrat Works [Internet]. 2014 [cited 2016 Mar 09];4(1):96-106. Available from: https://journals.lib.unb.ca/index.php/NW/article/view/21575

14. Vidal PEV, Pinheiro FV. O corpo na psicose no último ensino de Lacan. Psicol Rev[Internet]. 2015 [cited 2015 Nov 30];24(2):26578. Available from: http://revistas.pucsp.br/index.php/psicorevista/article/view/27799/19628

15. Miller JA. A invenção psicótica. Rev Opção Lacan[Internet]. 2003 [cited 2015 Nov 30];36:6-16. Available from: http://www.mom. arq.ufmg.br/mom/16_ish/04-referencias/textos/textos\%20psicanalise/invencao

16. Soller C. Las lecciones de las psicosis: tres conferencias en Buenos Aires. Foro Analítico del Río de La Plata[Internet]. 2011 [cited 2015 Nov 30]. Available from: http://www.forofarp.org/images/pdf/Colette2.pdf

17. Lima CM. Corpo e Sinthoma: tratamento do gozo em Freud e Lacan. Rev Estil Clín[Internet]. 2013 [cited 2015 Nov 30];18(1):18098. Available from: http://pepsic.bvsalud.org/pdf/estic/v18n1/a12v18n1.pdf

18. Lacan J. O Seminário VII. A ética da psicanálise. 1988 (1959-1960). 396p

19. Di Ciaccia A. La pratique à Plusieurs. In: Di Ciaccia A, Gutierréz M, Bori A. Habitar el discurso: el tratamiento en institución de los graves trastornos psíquicos. Asociación Psicoanalítica de Orientación Lacaniana[Internet]. 2006 [cited 2015 Nov 30];9-32. Available from: http://www.apol.org.mx

20. Laurent E. Ato e instituição. Almanaque On-Line- Rev Inst Psic Saúde Mental Minas Gerais[Internet]. Belo Horizonte. 2011 [cited 2015 Nov 30];5(8):1-7. Available from: http://www.institutopsicanalise-mg.com.br/almanaque.htm

21. Nightingale F. Notas sobre enfermagem: o que é e o que não é. São Paulo: Editora Cortez; 1989 (1859). 174p.

22. Freud S. A sutileza de um ato falho. In: Freud S. Novas conferências introdutórias sobre psicanálise e outros trabalhos. Rio de Janeiro: Imago, 1976 (1935). Edição Standard Brasileira das Obras completas de Sigmund Freud, vol. 22.p.285-7.

23. Januário LM, Tafuri MI. A relação transferencial para além da interpretação: reflexões a partir da teoria de Winnicott. Ágora[Internet]. 2011 [cited 2015 Nov 30];15(2): 259-74. Available from: http://www.scielo.br/pdf/agora/v14n2/a07v14n2.pdf

24. Naffah Neto A. The imaginative elaboration of body functioning and maternal holding: Winnicott and the formation of the psyche-soma. Int Forum Psycho[Internet]. 2013[cited 2015 Nov 30];22(1):60-6. Available from: http://www.tandfonline.com/toc/ spsy20/22/1

25. Pascal B. Pensamentos sobre o espírito e sobre o estilo - Artigo I. In: Pascal B. Pensamentos. 4ed. São Paulo: Editora Nova Cultural. 1988 (1670). Col. Os Pensadores. p. 37-47.

26. Miller JA. Coisas de fineza em psicanálise[Internet]. 2008 [cited 2015 Nov 30];70 p. Available from: http://institutopsicanalise-mg. com.br/horizontes/textos/licoes.pdf 